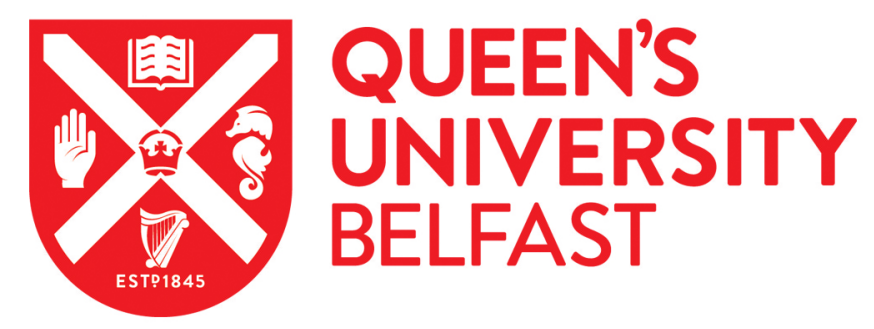

\title{
Accumulation and phytoavailability of benzo[a]pyrene in an acid sandy soil
}

Xing, W. Q., Luo, Y. M., Wu, L. H., Song, J., \& Christie, P. (2006). Accumulation and phytoavailability of benzo[a]pyrene in an acid sandy soil. Environmental Geochemistry and Health, 28(1-2), 153-158.

https://doi.org/10.1007/s10653-005-9026-9

\section{Published in:}

Environmental Geochemistry and Health

\section{Queen's University Belfast - Research Portal:}

Link to publication record in Queen's University Belfast Research Portal

\section{General rights}

Copyright for the publications made accessible via the Queen's University Belfast Research Portal is retained by the author(s) and / or other copyright owners and it is a condition of accessing these publications that users recognise and abide by the legal requirements associated with these rights.

Take down policy

The Research Portal is Queen's institutional repository that provides access to Queen's research output. Every effort has been made to ensure that content in the Research Portal does not infringe any person's rights, or applicable UK laws. If you discover content in the Research Portal that you believe breaches copyright or violates any law, please contact openaccess@qub.ac.uk. 


\title{
Accumulation and phytoavailability of benzo[a]pyrene in an acid sandy soil
}

\author{
Weiqin Xing ${ }^{1}$, Yongming Luo ${ }^{1,3}$, Longhua $\mathrm{Wu}^{1}{ }^{\text {, Jing Song }}{ }^{1}$ \& Peter Christie ${ }^{2}$ \\ ${ }^{1}$ Soil and Environmental Bioremediation Research Center, State Key Laboratory of Soil and Sustainable \\ Agriculture, Institute of Soil Science, Chinese Academy of Sciences, 210008 Nanjing, China \\ ${ }^{2}$ Agricultural and Environmental Science Department, Queen's University Belfast, Newforge Lane, \\ BT9 5PX Belfast, UK \\ ${ }^{3}$ Author for correspondence (e-mail: ymluo@issas.ac.cn)
}

Key words: acidic sandy soil, PAHs, phytoavailability, polycyclic aromatic hydrocarbons, ryegrass

\begin{abstract}
Effects of benzo[a]pyrene $(\mathrm{B}[\mathrm{a}] \mathrm{P})$ on ryegrass (Lolium perenne $\mathrm{L}$.) growth, plant accumulation and dissipiation of $\mathrm{B}[\mathrm{a}] \mathrm{P}$ in a red sandy soil (Hapli-Udic Argosol) were studied in a pot experiment. The plants were grown for 61 days in soil spiked with $\mathrm{B}[\mathrm{a}] \mathrm{P}$ at $0,12.5,25$ and $50 \mathrm{mg} \mathrm{kg}^{-1}$. Control pots without plants were also set up. Soil extractable B[a]P, plant shoot and root biomass, and concentrations of B[a]P in plant shoots and roots were determined. Ryegrass biomass was increased by addition of $\mathrm{B}[\mathrm{a}] \mathrm{P}$ and root $\mathrm{B}[\mathrm{a}] \mathrm{P}$ concentrations were significantly correlated with $\mathrm{B}[\mathrm{a}] \mathrm{P}$ application rate, but no such correlation was found for shoot $\mathrm{B}[\mathrm{a}] \mathrm{P}$ concentrations. This indicates that $\mathrm{B}[\mathrm{a}] \mathrm{P}$ enhanced the growth of the ryegrass. The extractable $\mathrm{B}[\mathrm{a}] \mathrm{P}$ concentration in the planted soil was significantly lower than that in the unplanted control soil at the rate of $50 \mathrm{mg} \mathrm{B}[\mathrm{a}] \mathrm{P} \mathrm{kg}{ }^{-1}$. This indicates that ryegrass may help to dissipate $\mathrm{B}[\mathrm{a}] \mathrm{P}$ in soil at concentrations over $50 \mathrm{mg} \mathrm{kg}^{-1}$ soil although the mechanism for this is not understood.
\end{abstract}

\section{Introduction}

Polycyclic aromatic hydrocarbons (PAHs) result from the incomplete combustion of organic matter and automobile exhausts, coal or wood combustion, and coal-fired power plants. Low molecular weight PAHs such as naphthalene and phenanthrene are used for synthesis of detergents, dyes and mothballs. PAHs have low solubility and high persistency and many of them are toxic, mutagenic and carcinogenic.

Plants take up PAHs through the roots or absorb gaseous or particulate PAHs through the leaves (Edwards 1988; Simonich \& Hites 1995). Low molecular weight PAHs can be absorbed through plant roots and be transported to aboveground parts, while high molecular weight PAHs can be strongly adsorbed on the root epidermis (Wild \& Jones 1992; Kipopoulou et al. 1999). In
PAH-polluted soil, more PAHs are found in plant roots than in leaves. Monocotyledons such as ryegrass have often been selected for the remediation of PAH polluted soil (Günther et al. 1996; Binet et al. 2000a, b; Fang et al. 2001) because of their robust root systems. Research has indicated that ryegrass aids the dissipation of 5- and 6-ring PAHs in soil because of the increase in rhizosphere microorganisms (Binet et al. 2000a).

The red sandy soils (Hapli-Udic Argosols) which are acid and contain low organic carbon, are frequently found in hilly areas in south China (Hseung \& Li 1987). In areas where there has been rapid development of manufacturing industry, the red sandy soils are often exposed to organic pollutants. Soil organic carbon is an important soil property affecting dissipation and bioavailability of PAHs in soil, thus the behavior of the high molecular weight benzo[a]pyrene $(\mathrm{B}[\mathrm{a}] \mathrm{P})$ in red sandy soil may be 
different from that in soils with higher clay and organic matter contents. However, there is very little published information on pollution of HapliUdic Argosols. Ding et al. (2002a) found that adding phenanthrene to a red sandy soil decreased the microbial population. The objective of the present study was to investigate the dissipation and phytoavailability of $\mathrm{B}[\mathrm{a}] \mathrm{P}$ in a red sandy soil and the effect of ryegrass plants on its dissipation.

\section{Materials and methods}

Samples of the arable layer $(0-20 \mathrm{~cm})$ of a red sandy soil (Hapli-Udic Argosol) were collected from an experimental farm in Yingtan, Jiangxi province, south China. The soil samples were air-dried and homogenized. The soil had the following properties: organic carbon, $2.88 \mathrm{~g} \mathrm{~kg}^{-1}$; total nitrogen $(\mathrm{N})$, $0.71 \mathrm{~g} \mathrm{~kg}^{-1}$; total phosphorus (P), $0.72 \mathrm{~g} \mathrm{~kg}^{-1} ; \mathrm{pH}$ $\left(\mathrm{H}_{2} \mathrm{O}\right)$ 5.0; cation exchange capacity (CEC), $2.19 \mathrm{cmol} \mathrm{kg} \mathrm{kg}^{-1}$; and sand, silt and clay contents of 57.9, 26.9 and $15.2 \%(\mathrm{v} / \mathrm{v})$, respectively. The soil was spiked with $0.15 \mathrm{~g} \mathrm{~N} \mathrm{~kg}^{-1}$ in the form of urea before the experiment.

Seeds of ryegrass (Lolium perenne L. cv. Abundant) were purchased from Jiangsu Agricultural Academy, Nanjing. B[a]P (purity: >97\%) was obtained from Sigma Chemical Co., USA.

Soil was spiked with B[a]P at 0, 12.5, 25 and $50 \mathrm{mg} \mathrm{kg}^{-1}$ soil with appropriate amount of B[a]P acetone solution. Each pot was adjusted to $20 \mathrm{~mL}$ of acetone application and soil was equilibrated for $10 \mathrm{~d}$ after the addition of $\mathrm{B}[\mathrm{a}] \mathrm{P}$ for the acetone to evaporate, and the soils were thoroughly mixed by hand and placed in pots. Seeds of ryegrass were surface sterilized by soaking in $30 \%(\mathrm{v} / \mathrm{v}) \mathrm{H}_{2} \mathrm{O}_{2}$ for $20 \mathrm{~min}$ and washed several times in distilled water and were germinated for $3 \mathrm{~d}$ before planting. All treatments were set up in triplicate and planted with ryegrass. For each treatment an unplanted control pot was also prepared.

Each pot contained $500 \mathrm{~g}$ air-dried soil in which 25 ryegrass seeds were planted and thinned to 15 plants $15 \mathrm{~d}$ after germination. The soil surface was covered with a layer of silica sand $(\sim 50 \mathrm{~g})$ to minimize B[a]P volatilization (Binet et al. 2000b, 2001). The pots were kept in the dark until germination occurred, then arranged in a greenhouse $\left(25^{\circ} \mathrm{C} /\right.$ $20{ }^{\circ} \mathrm{C}$ day/night, 12 h day, 4500-7300 lux) and were completely randomized. Pots were watered daily by weight to $60 \%$ of water holding capacity (WHC) with deionized water during the experiment.

The plants were harvested $61 \mathrm{~d}$ after planting and washed with deionized water, and the shoots were separated from the roots with scissors, oven dried at $75^{\circ} \mathrm{C}$ and weighed. Soil from each pot was mixed, and about $150 \mathrm{~g}$ was sampled and air-dried at room temperature. Three soil samples were obtained from the unplanted soil after thorough mixing. Soil and plant samples were ground in an agate mortar, passed through a 100 -mesh sieve and kept at $4{ }^{\circ} \mathrm{C}$.

The $\mathrm{B}[\mathrm{a}] \mathrm{P}$ extraction procedure for the soil and plant samples was a modification of that of Song et al. (1995). Briefly, soil (5 g dry matter basis) $\mathrm{B}$ [a]P was extracted with $20 \mathrm{~mL}$ dichloromethane using ultrasonic agitation for $2 \mathrm{~h}$ at a temperature of $<40{ }^{\circ} \mathrm{C}$. After centrifugation, $5 \mathrm{~mL}$ of the supernatant solution was evaporated. The remainder was then dissolved with $2 \mathrm{~mL}$ of cyclohexane, $0.5 \mathrm{~mL}$ of the solution was added to a silica gel column and eluted with a mixture of $n$-hexane/ dichloromethane $(1: 1, \mathrm{v} / \mathrm{v})$. Two $\mathrm{mL}$ of eluate was collected after the first $1 \mathrm{~mL}$ of the eluate was discarded. The $2 \mathrm{~mL}$ solution was blown dry with nitrogen and dissolved in acetonitrile. For the analysis, $50 \mu \mathrm{L}$ samples were injected into a high performance liquid chromatography unit (HPLC, Shimadzu, Japan). The HPLC was fitted with a fluorescence detector and a VP-ODS column (serial No. 9122504, 150L×4.6). Acetonitrile-water $(90: 10, \mathrm{v} / \mathrm{v})$ was used as the mobile phase and the

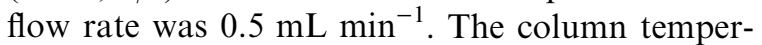
ature was maintained at $30{ }^{\circ} \mathrm{C}$. The wavelengths of excitation and emission were 296 and $404 \mathrm{~nm}$, respectively. For extraction of plant samples, $0.1 \mathrm{~g}$ sample was extracted with $10 \mathrm{~mL}$ methanol and repeated twice, the extracted solution was mixed and water was removed from the eluate with $5 \mathrm{~g}$ anhydrous $\mathrm{Na}_{2} \mathrm{SO}_{4}$. Other procedures were the same as for soil analysis. This method gave a recovery of $80-96 \%$.

Values presented are the means of triplicates, data were examined by analysis of variance (ANOVA) were compared by LSD at the 5\% level. Linear regression was carried out between soil and plant properties and soil extractable $\mathrm{B}[\mathrm{a}] \mathrm{P}$. For soil extractable $\mathrm{B}[\mathrm{a}] \mathrm{P}$, planted and unplanted soil were compared by $t$-test. Bioconcentration factors $(\mathrm{BCF}-\mathrm{B}[\mathrm{a}] \mathrm{P}$ concentration in fresh parts of plant/B[a]P concentration in dry soil) were calculated for each pot. 


\section{Results}

\section{Soil $B[a] P$ rate and ryegrass growth}

Figure 1 shows the ryegrass dry matter yield under different soil $\mathrm{B}[\mathrm{a}] \mathrm{P}$ rates. No differences were found in root dry weight but shoot dry weight differed among the soil $\mathrm{B}[\mathrm{a}] \mathrm{P}$ rates $(p<0.05)$. A significant positive correlation was found between soil extractable B[a]P and shoot dry mass $(p<0.05)$ but no such correlation was found between root dry yield and soil extractable B[a]P.

\section{Soil $B[a] P$ and ryegrass $B[a] P$ uptake}

Ryegrass shoot $\mathrm{B}[\mathrm{a}] \mathrm{P}$ concentration tended to increase with soil $\mathrm{B}[\mathrm{a}] \mathrm{P}$ rate, but no significant difference was found. Root $\mathrm{B}[\mathrm{a}] \mathrm{P}$ concentration was significantly affected by soil $\mathrm{B}[\mathrm{a}] \mathrm{P}$ rates $(p<0.01)$ (Figure 1), and was also affected significantly by soil extractable $\mathrm{B}[\mathrm{a}] \mathrm{P} \quad(p<0.01)$ (Table 1). More $\mathrm{B}[\mathrm{a}] \mathrm{P}$ was found in ryegrass roots than in shoots. However, in soil with low B[a]P concentration, a higher proportion of $\mathrm{B}[\mathrm{a}] \mathrm{P}$ migrated to the plant roots, which resulted in a BCF $>1$ (Table 2). Plant shoot uptake of B[a]P was less than $0.0012 \%$ of the amount applied to the soil at 12.5, 25 and $50 \mathrm{mg} \mathrm{B}[\mathrm{a}] \mathrm{P} \mathrm{kg} \mathrm{kg}^{-1}$ soil rates, while root uptake amounted to $0.081 \%, 0.056 \%$ and $0.048 \%$ of the quantity applied.

\section{$B[a] P$ rates and soil extractable $B[a] P$} after harvest

No statistically significant difference was found between planted soil and unplanted soil in soil extractable $\mathrm{B}[\mathrm{a}] \mathrm{P}$ at the soil $\mathrm{B}[\mathrm{a}] \mathrm{P}$ rates of $0,12.5$

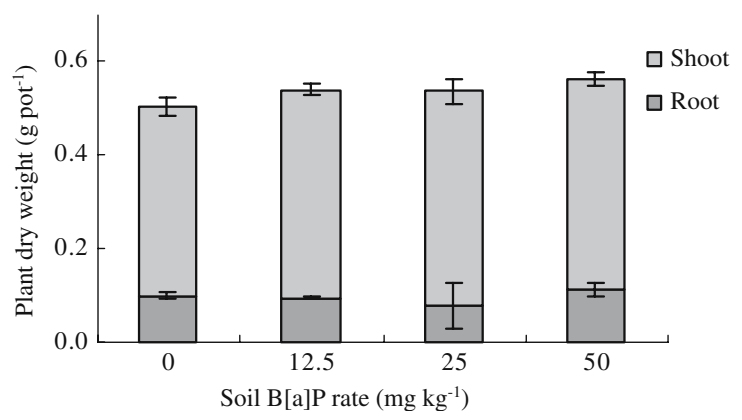

Fig. 1. Plant dry matter yield under different levels of B[a]P in an acid sandy soil.
Table 1. Correlations between ryegrass plant dry mass, B[a]P uptake and soil extractable B[a]P after harvest.

\begin{tabular}{ll}
\hline \multicolumn{2}{l}{ Dependent variable Regression equation } \\
\hline $\begin{array}{l}\text { Plant dry matter } \\
\text { yield (PDM) }\end{array}$ & $\mathrm{PDM}=0.5194+0.0014 \mathrm{~B}[\mathrm{a}] \mathrm{P} r=0.619^{*}$ \\
$\begin{array}{l}\text { Shoot dry matter } \\
\text { yield (SDM) }\end{array}$ & $\mathrm{SDM}=0.4287+0.0009 \mathrm{~B}[\mathrm{a}] \mathrm{P} r=0.595^{*}$ \\
$\begin{array}{l}\text { Root dry matter } \\
\text { yield (RDM) }\end{array}$ & $\mathrm{RDM}=0.0907+0.005 \mathrm{~B}[\mathrm{a}] \mathrm{P} r=0.514$ \\
$\begin{array}{l}\text { Shoot } \mathrm{B}[\mathrm{a}] \mathrm{P} \\
\text { concentration } \\
\begin{array}{l}\text { (SB[a]P) } \\
\text { Root } \mathrm{B}[\mathrm{a}] \mathrm{P}\end{array}\end{array}$ \\
$\begin{array}{l}\text { concentration } \\
(\mathrm{RB}[\mathrm{a}] \mathrm{P})\end{array}$
\end{tabular}

*, $p<0.05 ; * *, p<0.01$.

and $25 \mathrm{mg} \mathrm{kg}^{-1}$. At the rate of $50 \mathrm{mg} \mathrm{B}[\mathrm{a}] \mathrm{P} \mathrm{kg}$, planted soil had a significantly lower concentration of extractable B[a]P $(p<0.05)$ (Figure 3). Extractable $\mathrm{B}[\mathrm{a}] \mathrm{P}$ amounted to $30.8,40.8$ and $62.6 \%$ at the rates of $12.5,25$ and $50 \mathrm{mg}$ $\mathrm{B}[\mathrm{a}] \mathrm{P} \mathrm{kg}^{-1}$ for the unplanted soil, and the corresponding values for the planted soil were 44.0, 55.8 and $40.9 \%$.

\section{Discussion}

As the number of benzene rings increases, the solubility of PAHs decreases rapidly, their toxicity meanwhile decreasing. Studies have indicated that naphthalene was 20 times more toxic than high molecular weight PAHs (Sims \& Overcash, 1983; Chaineau et al. 1997). At the soil rate of $500 \mathrm{mg} \mathrm{kg}^{-1}$, phenanthrene depressed the growth of ryegrass shoots (Ding et al. 2002b). Studies have established that plant growth was stimulated by PAHs with more benzene rings in certain concentration ranges, and one possible explanation is that they have a structure similar to that of the plant growth stimulator gibberellin (Graf \& Nowak

Table 2. Bioconcentration factors (BCF, $\left.\mathrm{mg} \mathrm{B}^{\mathrm{a}}\right] \mathrm{P} \mathrm{kg}^{-1}$ fresh plant $\left./ \mathrm{mg} \mathrm{B}^{\mathrm{B}} \mathrm{a}\right] \mathrm{P} \mathrm{kg}^{-1}$ dry soil) of ryegrass plants in $\mathrm{B}[\mathrm{a}] \mathrm{P}$ polluted soil.

\begin{tabular}{llll}
\hline Plant part & \multicolumn{3}{c}{ Soil B[a]P rate $\left(\mathrm{mg} \mathrm{kg}^{-1}\right)$} \\
\cline { 2 - 4 } & 12.5 & 25 & 50 \\
\hline Roots & 1.246 & 0.5669 & 0.5884 \\
Shoots & 0.004895 & 0.002791 & 0.002343 \\
\hline
\end{tabular}


1966). $\mathrm{B}[\mathrm{a}] \mathrm{P}$ will have a higher bioavailability in the red sandy soil in this work which has a low content of organic carbon, clay particles, and low CEC, but our work still showed that under a soil rate of $50 \mathrm{mg} \mathrm{B}[\mathrm{a}] \mathrm{P} \mathrm{kg}^{-1}$ or less, no negative effect of $\mathrm{B}[\mathrm{a}] \mathrm{P}$ on ryegrass growth was found. Carrot and potato growth was stimulated in soil containing 16 USEPA PAHs at a total PAH concentration $>1200 \mathrm{mg} \mathrm{kg}^{-1}$ (in two of the treatments, the concentrations of B[a]P were 144 and $299 \mathrm{mg} \mathrm{kg}^{-1}$, respectively) (Fismes et al. 2002). In fact, a positive effect of PAHs on growth of organisms has been noted by Graf (1965), who made early observations that PAHs can increase the cell height of algae. Subsequently similar effects were found on the yields of cabbage, tobacco and rice (Graf \& Nowak 1966) and the higher the molecular weight, the greater the stimulation.

Judged from the result of the present work, plants can take up $\mathrm{B}[\mathrm{a}] \mathrm{P}$, but only a very minute portion can be found in the upper parts, perhaps due to the high lipid solubility. The transport of $\mathrm{B}[\mathrm{a}] \mathrm{P}$ from plant roots to shoots is hypothesized to be passive and driven by mass flow (Fismes et al. 2002). Furthermore, leaf absorption of gaseous $\mathrm{B}[\mathrm{a}] \mathrm{P}$ from the air may also contribute to shoot $\mathrm{B}[\mathrm{a}] \mathrm{P}$ uptake. In our experiment shoot $\mathrm{B}[\mathrm{a}] \mathrm{P}$ at different soil $\mathrm{B}[\mathrm{a}] \mathrm{P}$ rates were very similar, even including the plants grown in soil with no B[a]P (Figure 2). Because all leaves share the same air, their absorption of $\mathrm{B}[\mathrm{a}] \mathrm{P}$ may be similar, thus shoot $\mathrm{B}[\mathrm{a}] \mathrm{P}$ concentrations under different soil $\mathrm{B}[\mathrm{a}] \mathrm{P}$ treatments may become similar. Significant bioremediation of $\mathrm{B}[\mathrm{a}] \mathrm{P}$ by ryegrass was found only at the rate of $50 \mathrm{mg} \mathrm{B}[\mathrm{a}] \mathrm{P} \mathrm{kg}^{-1}$, and the effect was not discernible at lower $\mathrm{B}[\mathrm{a}] \mathrm{P}$ rates.
The bioremediation of organic pollutants in soil is affected by soil properties (Sung et al. 2001). B[a]P is highly lipid-soluble and can be easily absorbed by soil organic matter, resulting in low availability to plants (Cuny et al. 1999). Therefore if a soil is rich in organic matter, the organic pollutant is readily to distributed within the soil solid phase, a smaller proportion enters the porewater, and the $\mathrm{B}[\mathrm{a}] \mathrm{P}$ becomes less available to plants (Sung et al. 2001). We would expect $\mathrm{B}[\mathrm{a}] \mathrm{P}$ to be more available to plants in the red sandy soil with its relatively low clay and organic matter content.

Samsoe-Petersen et al. (2002) found no correlation between plant root $\mathrm{B}[\mathrm{a}] \mathrm{P}$ concentrations and soil $\mathrm{B}[\mathrm{a}] \mathrm{P}$ rates and they concluded that $\mathrm{B}[\mathrm{a}] \mathrm{P}$ could not be absorbed by plants. Other work showed that the $\mathrm{B}[\mathrm{a}] \mathrm{P}$ concentration of carrot epidermis was correlated with soil $\mathrm{B}[\mathrm{a}] \mathrm{P}$ rates (Borneff et al. 1973). Wang \& Yu (1984) reported that $\mathrm{B}[\mathrm{a}] \mathrm{P}$ could be transported in corn plants in a hydroponic experiment, and the $\mathrm{B}[\mathrm{a}] \mathrm{P}$ concentration of the shoots was proportional to the concentration in the growth media. In the present work the shoot $\mathrm{B}[\mathrm{a}] \mathrm{P}$ concentrations were not correlated with soil $\mathrm{B}[\mathrm{a}] \mathrm{P}$ rates but root $\mathrm{B}[\mathrm{a}] \mathrm{P}$ concentrations were positively correlated with soil $\mathrm{B}[\mathrm{a}] \mathrm{P}$ rates, suggesting that it is difficult for $\mathrm{B}[\mathrm{a}] \mathrm{P}$ to be transported to the aerial parts of ryegrass from the soil. The results of Wang \& Yu (1984) are likely due to the higher availability of $\mathrm{B}[\mathrm{a}] \mathrm{P}$ in liquid growth media.

The results of the present study suggest that the highly lipid soluble B[a]P can enter the roots of ryegrass but this is not a positive process driven by plant energy. This passive process is controlled by

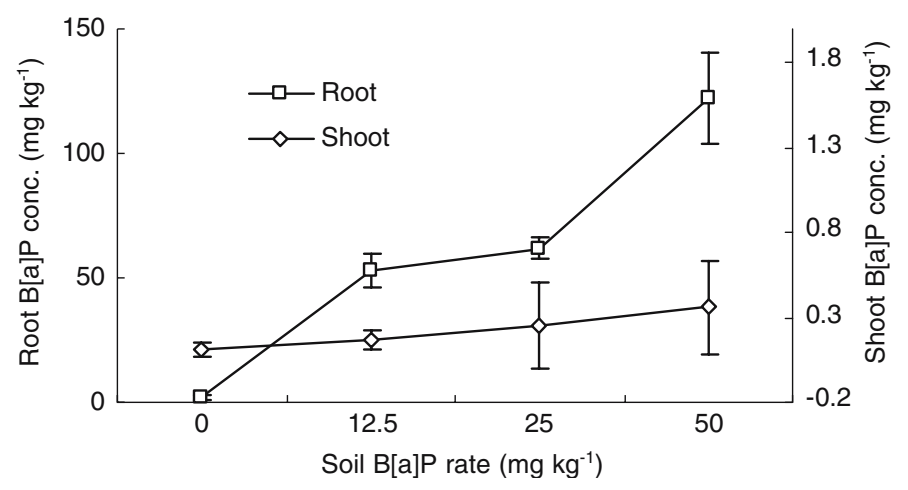

Fig. 2. Concentrations of $\mathrm{B}[\mathrm{a}] \mathrm{P}$ in ryegrass under different $\mathrm{B}[\mathrm{a}] \mathrm{P}$ levels in an acid sandy soil. 
BENZO[A]PYRENE IN AN ACID SANDY SOIL 157

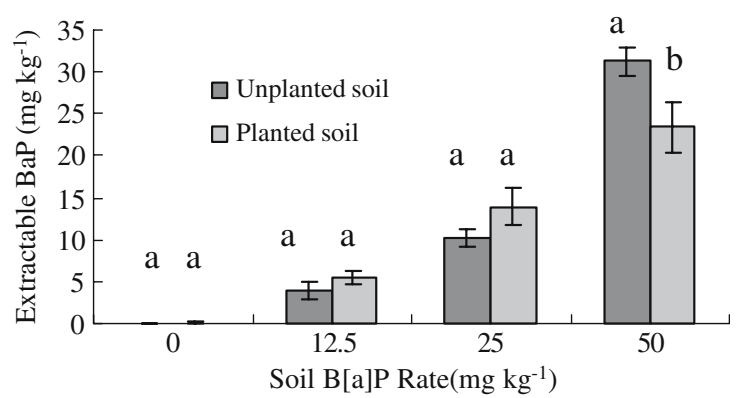

Fig. 3. Extractable B[a]P in planted and unplanted soil after harvest.

the concentration gradient between soil and roots. This gradient is composed of the $\mathrm{B}[\mathrm{a}] \mathrm{P}$ concentration in the soil and gibberellin-like compounds in the roots because they have similar structures. When the $\mathrm{B}[\mathrm{a}] \mathrm{P}$ concentration in the soil exceeded the concentration of root gibberellin-like compounds, a positive concentration gradient may have formed and $\mathrm{B}[\mathrm{a}] \mathrm{P}$ then driven into the plant roots by this concentration gradient. As a result, when the concentration difference between soil and roots does not appear, the positive correlation between soil rate and root concentration is also unlikely to appear, and this may explain the apparent absence of a correlation between soil $\mathrm{B}[\mathrm{a}] \mathrm{P}$ rate and root $\mathrm{B}[\mathrm{a}] \mathrm{P}$ concentration found by other workers (Samsoe-Petersen et al. 2002).

\section{Conclusions}

In the acid sandy soil, ryegrass shoot growth was stimulated by soil $\mathrm{B}[\mathrm{a}] \mathrm{P}$ rate $\leq 50 \mathrm{mg} \mathrm{kg}^{-1}$ and root growth was unaffected by spiking with $\mathrm{B}[\mathrm{a}] \mathrm{P}$. Most of the $\mathrm{B}[\mathrm{a}] \mathrm{P}$ in ryegrass was found in the roots, and the concentration was positively correlated with soil $\mathrm{B}[\mathrm{a}] \mathrm{P}$ rates. However, no correlation was found between soil $\mathrm{B}[\mathrm{a}] \mathrm{P}$ rate and shoot $\mathrm{B}[\mathrm{a}] \mathrm{P}$ concentration. Ryegrass $\mathrm{B}[\mathrm{a}] \mathrm{P}$ uptake amounts to a very small percent of the $\mathrm{B}[\mathrm{a}] \mathrm{P}$ applied to the soil. Ryegrass plants aided the dissipation of soil $\mathrm{B}[\mathrm{a}] \mathrm{P}$ only at a concentration of $50 \mathrm{mg} \mathrm{kg}^{-1}$, with no positive effect found at lower additon rates.

\section{Acknowledgements}

The authors are grateful for grant-aided support from the National Science Foundation of China
(Nos. 40031010, 40432005), and from the Major State Basic Research and Development Program of the People's Republic of China (2002CB41 080910).

\section{References cited}

Binet P, Portal JM, Leyval C. 2000a Dissipation of 3-6-ring polycyclic aromatic hydrocarbons in the rhizosphere of ryegrass. Soil Biol. Biochem 32, 2011-2017.

Binet P, Portal JM, Leyval C. 2000b Fate of polycyclic aromatic hydrocarbons (PAHs) in the rhizosphere and mycorrhizosphere of ryegrass. Plant Soil 227, 207-213.

Binet P, Portal JM, Leyval C. 2001 Application of GC-MS to the study of anthracene disappearance in the rhizosphere of ryegrass. Org Geochem 32, 217-222.

Borneff J, Farkazdi G, Glathe H, Kunte H. 1973 The fate of polycyclic aromatic hydrocarbons in experiments using sewage sludge-garbage composts as fertilizers. Zentralbl Bakteriol Mikrobiol Hyg [B] 157, 151-164.

Chaineau CH, Morel JL, Oudot J. 1997 Phytotoxicity and plant uptake of fuel oil hydrocarbons. J Environ Qual 26, 1478-1483.

Cuny P, Faucet J, Acquaviva M, Bertrand JC, Gilewicz M. 1999 Enhanced biodegradation of phenanthrene by a marine bacterium in the presence of synthetic surfactant. Lett Appl Microbiol 29, 242-245.

Ding K, Luo Y, Liu S, Li Z, 2002a Effect of phenanthrene on microorganism in flooded soil. Soils 34, 229-232, 236.

Ding K, Luo Y, Liu S, Li Z. 2002b A preliminary study of remediation of phenanthrene polluted soil with ryegrass. Soils 34, 233-236.

Edwards NT 1988. Assimilation and metabolism of polycyclic aromatic hydrocarbons by vegetation - an approach to this controversial issue and suggestions for future research, pp. 211-229 Cook \& Dennis Polycyclic Aromatic Hydrocarbons: A Decade of Progress. 10th Int. Symp, Battelle Press, Columbus, OH Ed. Book.

Fang C, Radosevich M, Fuhrmann JJ. 2001 Atrazine and phenanthrene degradation in grass rhizosphere soil. Soil Biol Biochem 33, 671-678.

Fismes J, Perrin-Ganier C, Emperear-Bissonnet P, Morel JL. 2002 Soil-to-root transfer and translocation of polycyclic aromatic hydrocarbons by vegetables grown on industrial contaminated soils. J Environ Qual 31, 1649-1656.

Graf W. 1965 On the natural occurrence and importance of carcinogenic polycyclic aromatic hydrocarbons. Med Klin 60, 561.

Graf W, Nowak W. 1966 Promotion of grown in lower and higher plants by carcinogenic polycyclic aromatics. Arch $\mathrm{Hyg}$ Bakteriol 150, 513-528.

Günther T, Dornberger U, Fritsche W. 1996 Effect of ryegrass on biodegradation of hydrocarbons in soil. Chemosphere 33, 203-215.

Hseung Y, Li C-K. 1987 Soils of China, Beijing, China: Science Press, pp. 39-66.

Kipopoulou AM, Manoli E, Samara C. 1999 Bioconcentration of polycyclic aromatic hydrocarbons in vegetables grown in an industrial area. Environ Pollut 106, 369-380. 
Samsoe-Petersen L, Larrsen EH, Larsen PB, Bruun P. 2002 Uptake of trace elements and PAHs by fruit and vegetables from contaminated soil. Environ Sci Technol 36, 3057-3063.

Simonich SL, Hites RA. 1995 Organic pollutant accumulation in vegetation. Environ Sci Technol 29, 2905-2914.

Sims RC, Overcash MR. 1983 Fate of polynuclear aromatic compounds (PNAs) in soil-plant systems. Residue Rev 33, 1-68.

Song Y, Ou Z, Sun T, Yediler A, Lorinci G, Kettrup A. 1995 Analytical method of polycyclic aromatic hydrocarbons (PAHs) in soil and plant samples. Chin J Appl Ecol 6, 92-96.
Sung K, Corapcioglu Y, Drew MC, Munster CL. 2001 Plant contamination by organic pollutants in phytoremediation. J Environ Qual 30, 2081-2090.

Wang C, Yu S. 1984 Absorption of B[a]P by corn roots and its accumulation in the plants. Acta Sci Circumst 4, 222-232.

Wild SR, Jones KC. 1992 Organic chemicals entering agricultural soils in sewage sludges: screening for their potential to transfer to crop plants and livestock. Sci Total Environ 119, 85-119. 